Universidade de Brasília

Faculdade de Direito

\title{
A DECLARAÇÃO UNIVERSAL DOS DIREITOS HUMANOS DAS NAÇÕES UNIDAS COMO MARCO PARA AS VISÕES DE DIREITOS HUMANOS NO ÂMBITO INTERNACIONAL
}

Fernanda Moura Queiroz Santos de Oliveira

Matrícula: 07/32443

Brasília

Dezembro de 2011 
Fernanda Moura Queiroz Santos de Oliveira

A DECLARAÇÃO UNIVERSAL DOS DIREITOS HUMANOS DAS NAÇÕES UNIDAS COMO MARCO PARA AS VISÕES DE DIREITOS HUMANOS NO

ÂMBITO INTERNACIONAL

Trabalho de Conclusão de Curso de graduação apresentado como requisito parcial à obtenção do título de bacharel em Direito pela Faculdade de Direito da Universidade de Brasília, Orientador: Prof. Dr. George Rodrigo Bandeira Galindo.

Brasília

Dezembro de 2011 
OLIVEIRA, Fernanda Moura Queiroz Santos. 1989

A Declaração Universal dos Direitos Humanos das Nações Unidas como marco para as visões de direitos humanos no âmbito internacional / Fernanda Moura Queiroz Santos de Oliveira. -2011.

Orientador: George Rodrigo Bandeira Galindo

Trabalho de conclusão de curso (graduação) - Universidade de Brasília, Curso de Direito, 2011.

1. Direitos Humanos. 2. Declaração Universal dos Direitos Humanos. 3.Concretização. I. GALINDO, George Rodrigo Bandeira. II. Universidade de Brasília. Curso de Graduação em Direito. III. A Declaração Universal dos Direitos Humanos das Nações Unidas como marco para as visões de direitos humanos no âmbito internacional 
Folha de Aprovação

\section{A DECLARAÇÃO UNIVERSAL DOS DIREITOS HUMANOS DAS NAÇÕES UNIDAS COMO MARCO PARA AS VISÕES DE DIREITOS HUMANOS NO ÂMBITO INTERNACIONAL}

Fernanda Moura Queiroz Santos de Oliveira

Matrícula: 07/32443

Trabalho final de conclusão de curso de graduação apresentada como requisito parcial à obtenção do título de bacharel em Direito pela Faculdade de Direito da Universidade de Brasília

Banca examinadora:

George Rodrigo Bandeira Galindo

Orientador

Natália Medina Araújo

Mestre em Direito pela Universidade de Brasília

Ana Paula da Cunha

Mestranda em Direito pela Universidade de Brasília

Brasília, 19 de dezembro de 2011. 
Às minhas meninas:

Pirrous, Fatness e Gêmola 


\section{Agradecimentos}

Agradeço aos meus pais, Laudimar e Luciana, que, incondicionalmente, de tudo fizeram para que eu seguisse o meu caminho. À minha irmãzinha Carmen, meu maior motivo de inspiração.

Agradeço ao professor George Galindo, meu orientador, que mesmo diante das dificuldades se dispôs a prestar suas contribuições de forma bastante solícita.

Agradeço aos demais membros da banca, Natália Medina e Ana Paula Cunha, por se disporem em tão pouco tempo a analisar o trabalho e ainda sim contribuírem com seus argumentos.

Agradeço, ainda, aos meus amigos e colegas que, de uma forma ou outra, contribuíram apoiando a minha graduação. 
O presente trabalho analisa a historiografia dos direitos humanos, sob a perspectiva de duas visões de conceituação, uma abrangente e outra restritiva estabelecendo como marco a Declaração Universal dos Direitos Humanos, com a utilização da ferramenta da periodização. A primeira parte do trabalho busca estabelecer a configuração dos direitos humanos ao longo da história, bem como delimitar o contexto histórico que possibilitou o surgimento da Declaração Universal dos Direitos Humanos nos moldes como foi designada. A segunda parte do trabalho traça uma análise acerca da influência de cada uma dessas visões de conceituação tanto para a elaboração da Declaração, como para a sua recepção, buscando projetar a questão das conseqüências aportadas pela escolha de cada uma dessas visões e objetivando perceber a influência delas no presente e no futuro, para que novos estudos se estabeleçam sobre o presente e possam contribuir com esclarecimento para algumas das dúvidas em relação à dificuldade de implementação dos direitos humanos. 


\begin{abstract}
The aim of this project is to analyze the historiography on human rights, through the perspective held by two concept views, one of which is encompassing by the time the other is restrictive, establishing as remark event the Universal Declaration of Human Rights, from the tool of periodization. The first part of the work intends to design the configuration of human rights throughout history, as well as to set up the historical context in which the emergence of the Universal Declaration of Human Rights was due to. The second part develops an analysis of the influence of each one of those concept views both on the drafting of the Declaration as on its acceptance, intending to forecast the issue of consequences brought up by the choice for one of the views in a way to realize its influences on both present and future, in order to enable new studies on the subject, that might clarify some reasons regarding the gap between conceiving and implementing human rights.
\end{abstract}




\section{LISTA DE SIGLAS}

$\mathrm{CDH}$ - Conselho ${ }^{1}$ de Direitos Humanos das Nações Unidas

DUDH - Declaração Universal dos Direitos Humanos

EUA - Estados Unidos da América

ONG - Organização Não Governamental

ONU - Organização das Nações Unidas

PIDCP - Pacto Internacional dos Direitos Civis e Políticos

PIDESC - Pacto Internacional dos Direitos Econômicos, Sociais e Culturais

UNESCO - Organização das Nações Unidas para a educação, a ciência e a cultura

\footnotetext{
${ }^{1}$ Antiga Comissão de Direitos Humanos das Nações Unidas, elevada ao status de Conselho em 15 de março de 2006, por deliberação da Assembléia Geral das Nações Unidas.
} 


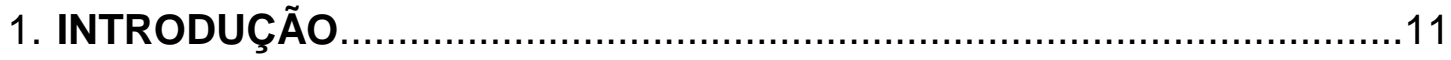

2. VISÕES DOS DIREITOS HUMANOS ................................................12

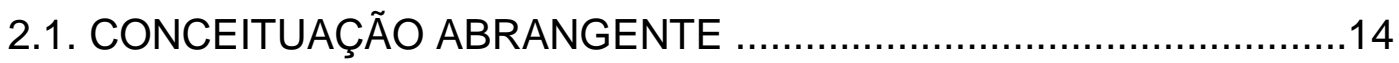

2.2. CONCEITUAÇÃO RESTRITIVA ...............................................18

3. A DECLARAÇÃO UNIVERSAL DOS DIREITOS HUMANOS DAS

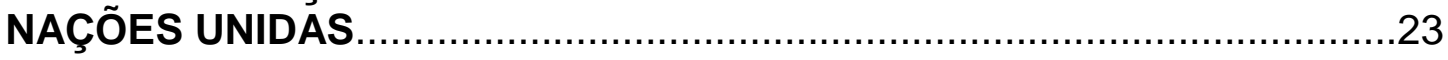

3.1. O CONTORNO DE DIREITOS HUMANOS UNIVERSAIS..................23

3.2. CONTEXTO HISTÓRICO E RASCUNHOS …..................................25

4.O PERÍODO PÓS-DECLARAÇÃO DE 1948 E AS VISÕES DE DIREITOS

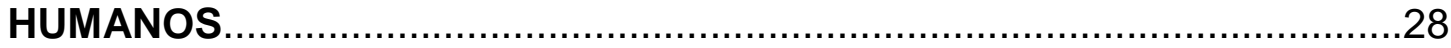

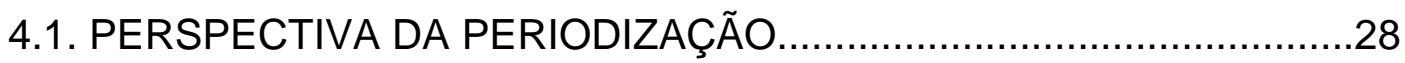

4.2. DISPARIDADE ENTRE OS SUJEITOS NORMA...............................35

4.3. A LINGUAGEM DOS DIREITOS HUMANOS E OS DIREITOS HUMANOS COMO LINGUAGEM...................................................43

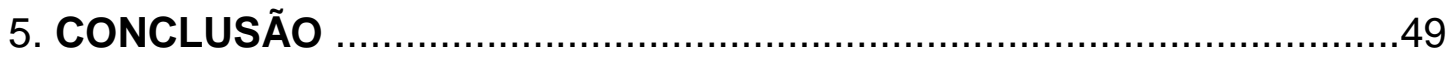

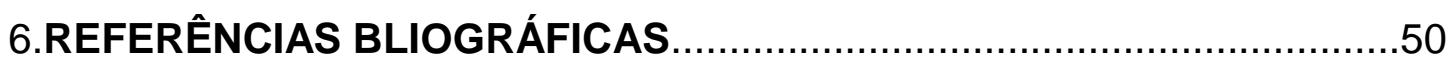




\section{INTRODUÇÃo}

O presente trabalho se insere nos estudos da historiografia dos direitos humanos ao propor uma análise do conceito de direitos humanos ao longo da história e suas repercussões.

Para tanto, o estudo se propõe analisar o entendimento de direitos humanos sob a óptica das duas principais correntes vigentes. A análise se estabelece sob o ponto de vista histórico, elegendo a Declaração Universal dos Direitos Humanos como marco paradigmático no direito internacional, por ser ela o documento mais importante sobre o assunto em escala global.

O trabalho pretende demonstrar que qualquer que seja a visão adotada sobre os direitos humanos, sua escolha possui consequências políticas e práticas, embora aqui não se pretenda demonstrar que consequências seriam essas.

Nesse sentido, procuramos perceber no primeiro capítulo qual a origem histórica de cada uma das correntes de conceituação dos direitos humanos e os fatores considerados necessários à sua configuração.

O capítulo seguinte ressalta o papel da DUDH, levando em consideração suas características, seu contexto histórico de surgimento, sua emergência como fator de universalidade para os direitos humanos e, sobretudo, sua posição de primeira positivação dos direitos humanos em escala global. Tal análise é feita tendo por base as duas correntes anteriormente mencionadas, buscando elucidar a contribuição de cada uma delas para a elaboração da DUDH.

A terceira parte busca explicitar a aplicação do método da periodização para a análise dos argumentos históricos a serem considerados em detrimento dos outros, ressaltando as diferenças existentes entre os sujeitos da norma e as implicações políticas de se adotar tais diferenças. $O$ estudo se encerra com uma reflexão acerca da semântica dos direitos humanos e do abismo existente entre os destinatários das disposições da DUDH.

Com isso, busca-se despertar o interesse do leitor, seja ele do meio acadêmico ou não, a fim de demonstrar que o tema é altamente relevante por possuir implicação direta na implementação dos direitos humanos nas mais diversas comunidades do globo. 


\section{VISÕES dos DiREITOS Humanos}

A questão do momento do surgimento dos direitos humanos é bastante controversa em toda a doutrina do direito internacional.

Dentre os pesquisadores do tema, o grupo se divide em dois grandes subgrupos, os quais, por sua vez, também possuem algumas divisões internas.

O fator que leva à divisão desses dois grandes subgrupos é, em suma, considerar a concepção de direitos humanos como algo rudimentar e naturalmente social ou, de outro lado, como reflexão de considerável complexidade oriunda da conjunção de alguns fatores.

É bem verdade que ambas correntes consideram os direitos humanos atuais como um produto da construção histórica que experimentou a sociedade contemporânea.

Entretanto, o que difere uma visão da outra é o fato de que a primeira, apesar de admitir que ocorreram mudanças ao longo do tempo, pensa tratar-se de direitos humanos desde que se tem registros na história antiga, ao passo que a segunda clama que só se podem considerar direitos humanos depois de uma reunião de condições bastante específicas.

Dessa questão, surgem duas consequências, uma principal e a outra subsidiária. A primeira seria a dificuldade de conceituação de direitos humanos e, em seguida, viria o percalço de atrelar as distinções de cada um dos significados atribuídos aos direitos humanos segundo esse parâmetro "evolutivo".

Em local algum conseguimos identificar o conceito exato de direitos humanos, nem sequer na DUDH. O primeiro grupo sustenta que estes possuem um caráter bastante fluido, no sentido de que a noção deles seria algo intrínseco ao indivíduo, ou no máximo fruto de uma construção social. Em contrapartida, a segunda linha defenderia a reunião de elementos bastante específicos e por vezes complexos para se constituir os direitos humanos, não dependendo eles necessariamente de positivação, mas de cognição prévia.

Sobre esse aspecto, talvez a melhor interpretação seja a da interação das duas visões. Afinal, "os direitos humanos são difíceis de determinar porque sua definição, e na verdade a sua própria existência, depende tanto das 
emoções quanto da razão." ${ }^{2}$ Sendo assim, contribuiriam tanto os fatos objetivos, aportados pela concepção restritiva, quanto a porção da emoção proposta pela concepção abrangente, que pode ser expressada pelo sentimento motivador de ações em prol dos direitos humanos.

Em relação à segunda dificuldade, esta consiste em reunir os grupos mínimos em cada um desses dois subgrupos, pois isso subentende a adoção de um marco para a satisfação da tal complexidade, já que todas as visões consideram fatores. Difícil é especificar quais fatores seriam os delimitadores.

Curiosamente, a escolha de um marco na história para análise de determinado conceito é justamente a proposta do presente trabalho, o da Declaração Universal dos Direitos Humanos para a visão dos direitos humanos no direito internacional.

Em relação à reunião de fatores que configurariam a pretendida complexidade capaz de dar os contornos atuais de direitos humanos, utilizaremos as taxonomias que os próprios autores sugerem.

Isto é, integrarão o primeiro grupo aqueles que identificarem características de direitos humanos em um período anterior às revoluções do século XVIII. Em contrapartida, o grupo dos restritivos será integrado por aqueles que não concebem a referência de direitos humanos até a modernidade.

Apesar de apresentarmos duas linhas com características aprioristicamente bem definidas, é possível perceber em cada uma delas elementos os quais seriam típicos da outra, sem que, contudo, reste prejudicada a divisão. Por sua vez, a divisão entre essas duas linhas se faz imperiosa uma vez que a adoção de uma corrente em detrimento da outra possui implicações práticas. O momento que se considera como aquele do surgimento dos direitos humanos serve como uma lupa para que estabeleçamos um padrão de comportamento em relação à receptividade do conceito de direitos humanos porventura agregado por outras culturas que não a ocidental moderna.

A primeira, por ser mais abrangente, e nessa medida mais flexível, permitiria a inclusão de outras realidades que na essência possuem a mesma configuração, mas que por alguma diferença de contexto, em relação aos diversos fatos experimentados por povos variados, se apresentam de forma distinta. Já a

\footnotetext{
${ }^{2}$ HUNT (2009, p. 24)
} 
restritiva, em decorrência de seus padrões mais rígidos, não é muito receptiva à ideia de considerar como práticas de direitos humanos práticas que, segundo ela, possuem outra natureza, as quais podem ser morais, religiosas, entre outras, mas que não denotam maiores reflexões sobre a utilização dos preceitos de direitos humanos.

\subsection{Conceituação abrangente}

A corrente de aplicação abrangente do conceito de direitos humanos tem diversos defensores. Sobre o aspecto abrangente, cabe informar que os direitos humanos são, para eles, uma expressão cognoscível desde as primeiras relações sociais das quais se tem registro escrito, em virtude de um sentimento inerente aos seres humanos quando do convívio em sociedade.

A defesa parte da ideia de que, indubitavelmente, o entendimento que temos hoje de direitos humanos não é o mesmo que se tinha em suas primeiras expressões. Contudo, são capazes de perceber que desde esse início da vida em sociedade, havia o que podemos considerar o embrião da ideia atual de direitos humanos, pois o sentimento é convertido em ações de resguardo do próximo em virtude de sua condição humana.

Acreditam e dispensam estudos sobre o fato de que diversos fatores foram sendo agregados ao longo da história, de acordo com a conformação temporal e geográfica, os quais permitiram que hoje tenhamos um conceito tão complexo.

Até mesmo os partidários da visão ampla por vezes discordam em relação aos argumentos históricos a se levarem em conta para a evolução do conceito de direito internacional.

No caso da obra conjunta dos autores DEVINE, HANSEN e WILD o sentimento de insatisfação que surge quando da perturbação da ordem em relação ao direito de um indivíduo não é por si só responsável por conceder a essa insatisfação a condição de direitos humanos. Embora a concepção de direito natural possa ser percebida antes mesmo da civilização grega clássica, é somente nela que esses autores consideram a primeira expressão do que se conhece hoje por direitos humanos. 
Isso porque o modelo político e religioso permitiu a assunção da singularidade do indivíduo a se relacionar tanto com os demais como com a polis. Essa característica não se confunde, contudo, com vinculação no sentido de responsabilidades por parte do estado em relação ao individuo, que é justamente o que diferencia os direitos humanos na modernidade.

Já o Império romano contribuiu para o padrão atual dos direitos humanos à media em que concebeu o que se pode considerar germe do caráter universal. Enquanto na Grécia não havia qualquer flexibilização em relação à figura dos cidadãos, em Roma mulheres, escravos e crianças gozavam de alguns desses direitos.

Quando abordado o tema da religião, DEVINE, HANSEN e WILD se restringem a tratar da tradição judaico-cristã que confere aos indivíduos uma relação de ligação divina com o criador. Não abordam as demais religiões do globo e, sobretudo, aportam a ideia de revelação divina, refutada pela maioria dos autores da mesma linha.

\begin{abstract}
O atual movimento de direitos humanos é "filho" do século XX e, mais especificamente uma herança dos terríveis crimes cometidos contra a humanidade durante a Segunda Guerra Mundial. [...] a força da tradição ocidental de preocupação com o bem-estar social - que existe desde pelo menos o período greco-romano, mas que vem sendo refinada e experimentada no cadinho das necessidades humanas, da guerra e da riqueza ao longo dos últimos três mil anos. Essas raízes deram origem a vigorosos troncos nascidos das revoluções inglesa, norte-americana e francesa, que produziram, em todo o ocidente, direitos jamais sonhados nos séculos XVII e XVIII. ${ }^{3}$
\end{abstract}

Apesar de a visão dos autores em comento ser abrangente sob o ponto de vista temporal, podemos perceber que diversos traços nos levam a concluir que geograficamente o conceito de direitos humanos fica bem restrito à civilização ocidental.

Inicialmente, por sequer atribuir qualquer menção às religiões que não as de tradição judaico-cristã. Posteriormente, em função do comentário expresso à tradição ocidental, se posicionando a respeito do fato de que a contribuição para a visão atual de direitos humanos teria surgido em decorrência dessa tradição.

\footnotetext{
3 DEVINE, HANSEN et WILD (2007, p. 165)
} 
Para ISHAY, o conceito de direitos humanos começa a se beneficiar ainda do conceito de irmandade das religiões antigas. Elas também são as responsáveis por considerar uma ética universal a todos seus seguidores, ainda que em algumas dessas religiões não haja positivação de qualquer natureza.

Ao contrário do que apontam DEVINE, HANSEN e WILD, a contribuição da Grécia antiga para a autora não teria sido a inaugural. Após o advento dos conceitos aportados pelas religiões, essa civilização teria sido a responsável por agregar o sentido da busca pela verdade como representação do justo. Ressalte-se que, para ela, a contribuição religiosa veio de valores compartilhados entre todas as religiões antigas.

No mesmo sentido sustenta LAUREN. Contudo, a essa perspectiva linear ele agrega à história dos direitos humanos uma conotação a partir de visões ${ }^{4}$ de direitos humanos, concedida por seus respectivos visionários diante de situações específicas.

Para ele, "the evolution of human rights thus has been - and continues to be - one of considerable complexity, involving interaction among these elements of vision, people and events in dynamic and often unanticipated ways." ${ }^{5}$

Apesar de o autor considerar o elevado grau de complexidade na evolução do conceito, como se pode apreender do extrato acima, mantém a nomenclatura desde a sua gênese. $E$ defende uma série de mudanças ao longo do tempo, as quais só seriam ocasionadas mediante a confluência de três realidades: visões, visionários e eventos.

Nesse diapasão, afirma que diante de determinadas situações de oscilação da ordem no resguardo dos direitos humanos, alguns indivíduos se veem compelidos a realizar reflexões não antes experimentadas, de forma a ter a transpor esse evento.

It is exactly these kinds of difficult, thought-and conscience-provoking questions that endow visions of human rights with a power that encourages, enables, or actually forces people to test existing values, reexamine their assumptions, and sometimes change their minds. For this reason, those who witnessed the evolution of international human rights at one stage or another constantly comments on the remarkable

\footnotetext{
4 "Visões" aqui se refere a um tema distinto do tratado no título do capítulo do presente trabalho, onde a alusão é ao sentido conceitual do termo, à carga semântica que cada uma das correntes confere ao brocardo "direitos humanos."

5 LAUREN (1998, p. 293) Tradução livre: A evolução dos direitos humanos internacionais então tem sido - e continua a ser de considerável complexidade, envolvendo interação entre esses elementos de visões, pessoas e eventos em dinâmica e freqüentes formas imprevistas.
} 
power of visions to transform society by "stirring the conscience of humanity" and "changing pattern of thought", even those entrenched with centuries of encumbered tradition behind them. ${ }^{6}$

...historical events of great consequence created not only a context but also the conditions for change.

Além da motivação externa dos acontecimentos aqui tidos como determinantes para encadear a atitude visionária, o doutrinador defende a interação desses com sentimentos internos do sujeito a empreender essas ações.

Althought visions possess this unusual degree of power and influence, they do not have the capacity to spring to life on their own or bring themselves to fruition. For this task, they need people, or what Nelson Mandella calls the heroes or heroines. ${ }^{8}$

Como é de se esperar da proposta, tais líderes surgiram nos mais diversos estratos da sociedade, e nas mais distintas épocas, de acordo com eventos determinantes.

Historicamente, são diversos os momentos que se podem citar em que houve a coexistência dessas três condições para a modificação do ideal de direitos humanos, cada um contribuindo com uma característica imprescindível ao modelo atual.

Ao exemplo das religiões que ao estabelecer noções de valores, buscando desenvolver um imperativo moral de obrigação para com o resto da humanidade, contribuíram para que fosse aberta discussão para a questão dos direitos. Em seguida, os filósofos aperfeiçoaram essas ideias, buscando a virtude e solidificando a ideia de contraprestação que ao exercício dos deveres corresponderia direito.

\footnotetext{
${ }^{6}$ LAUREN (1998, p. 282) Tradução livre: É exatamente esses tipos de dificuldades, pensamento e consciência, que levantam questões que dotam visões de direitos humanos que encorajam, possibilitam, ou realmente forçam as pessoas a testar valores pré-existentes, a reexaminar suposições, e algumas vezes mudar suas mentes. Por esta razão, aqueles que testemunharam a evolução dos direitos humanos internacionais de um estágio a outro constantemente comentam o poder excepcional das visões transformarem a sociedade "ativando a consciência da humanidade" e "mudando padrões de pensamento", mesmo aqueles arraigados de oneradas tradições por séculos.

7 LAUREN (1998, p. 290) Tradução livre: ...eventos históricos impactantes criaram não só o contexto, mas as condições para a mudança.

${ }^{8}$ LAUREN (1998, p. 284) Tradução livre: Apesar de as visões possuírem graus incomuns de poder e influência, elas não tem a capacidade de serem trazidas à tona por si sós ou de se colocar à implementação. Para cumprir esse objetivo, essas visões imprescindem de pessoas, o que Nelson Mandella costuma chamar de heróis ou heroínas.
} 


\section{2 Conceituação restritiva}

Os partidários da conceituação restritiva de direitos humanos são hoje a maioria dos escritores que se ocupam do tema dos direitos humanos no cenário internacional.

Seu posicionamento restritivo se dá, sobretudo, por conta do caráter instrumental que pretendem aplicar ao conceito. Ele seria instrumental sob dois aspectos: o primeiro, para utilização da academia; o segundo, para implementação real dos dispositivos.

Caso o emprego do termo não seja em sentido estrito, prejudica as produções acadêmicas, nas quais se faz imperiosa a utilização correta dos conceitos assim como pode afetar a implementação dos direitos humanos, os quais estariam sujeitos a uma relativização e, portanto, situados em terreno fértil para que abusos sejam cometidos.

Por essa razão, condicionam o conceito de direitos humanos à existência de certas características, mutáveis em razão do tempo e do espaço. Eles acreditam que a prática e a defesa dos direitos do indivíduo somente reúnem condições para se reportarem ao conceito de direitos humanos no Ocidente e assim mesmo do século XIX em diante.

Para Lynn HUNT, os direitos se tornam direitos humanos quando reúnem três características específicas:

Os direitos humanos requerem três qualidades encadeadas: devem ser naturais (inerentes nos seres humanos), iguais (os mesmos para todo mundo) e universais (aplicáveis por toda parte). Para que os direitos sejam direitos humanos, todos os humanos em todas as regiões do mundo devem possuí-los igualmente e apenas por causa de seu status como seres humanos. ${ }^{9}$

Essa visão parece ser assaz adequada à proposta da DUDH.

A ideia de se tratar de um direito natural está expressa na utilização do termo "declaração", contido no título da DUDH. Essa denominação pressupõe a existência do direito antes de sua redação; não se trata de um direito constituído naquela ocasião e sim anterior, inerente aos seres humanos.

Em contrapartida, a utilização de tal termo pode sugerir restrições ao conceito de direitos humanos. Uma vez que, sendo "declarados", entende-se por 
direitos humanos aqueles ali arrolados, como se fosse o caso de enumeração taxativa, o que iria de encontro à própria proposta da Declaração.

A universalidade, também expressa no próprio título, dispensa maiores comentários sobre sua compatibilidade com a previsão pelo documento em análise.

A despeito de ser perfeitamente compatível com a ideia de universalidade sugerida pela autora como condição de existência, o emprego do termo na Declaração parece não se esgotar nesse sentido. Para além do fato de se pretenderem aplicáveis "por toda parte" denota também a intenção de se perpetuarem no tempo. A universalidade almejada na DUDH subjuga tanto as barreiras espaciais quanto as temporais.

Ao que tudo indica, a escolha do termo também atua como reforço à terceira característica suscitada por HUNT, a igualdade, uma vez que se pretende universal em relação aos sujeitos a que se destina, ou seja, qualquer ser humano por sua simples condição de existência como tal.

A autora, apesar de identificar tais características como pressupostos da aplicabilidade do conceito de direitos humanos, não as considera bastantes para seu exercício. Segundo ela, "os direitos humanos só se tornam significativos quando ganham conteúdo político" ${ }^{10}$ e a reunião completa de fatores somente teria ocorrido pela primeira vez nas Declarações da Independência americana, esta em 1776, e dos Direitos do Homem e do Cidadão, de 1789.

Para MOYN, a história atua no mesmo sentido proposto por HUNT. Somente por meio da sucessão de acontecimentos específicos foi que alguns direitos se converteram em direitos humanos. Segundo o próprio MOYN, esses acontecimentos estão historicamente situados em um tempo bastante recente, justamente quando se inaugurou a questão da transcendência dos direitos humanos em oposição aos Estados, o que se deu com a concepção da modernidade.

True rights have long existed, but they were from the beginning part of the authority of the state, not invoked to transcend it. ${ }^{11}$

Aliás, ele considera que uma das poucas discussões relativas ao conceito dos direitos humanos que tem relevância é a da consideração dos direitos

\footnotetext{
${ }_{11}^{10}$ HUNT (2009, p. 19)

${ }^{11}$ MOYN (2010, p. 07) Tradução livre: Direitos verdadeiros existem há muito tempo, mas eram desde o princípio parte da autoridade do estado, não chamados a transcendê-lo.
} 
humanos somente a partir dessa circunstância, uma vez que apresentaria a consequência prática de ter sido ele a inaugurar a proteção do indivíduo enquanto tal, até mesmo oponível ao Estado soberano.

Of all the glaring confusions in the search for the "precursors" of human rights, one must have pride of place. Far from being sources of appeal that transcended state and nation, the rights asserted in early modern political revolutions and championed thereafter were central to the construction of state and nation, and led nowhere beyond until very recently. ${ }^{12}$

Como já elencado, é essa diferenciação do contexto que traz consequências à história dos direitos humanos e, por conseguinte, ao exercício desses direitos.

AFSHARI dedica todo um artigo para se opor ao posicionamento de LAUREN, mencionado na seção anterior. Seu posicionamento ideológico contrário a LAUREN, em confluência com a essência das proposições por ele defendidas, acaba por lhe classificar no grupo dos restritivos.

Ele critica justamente o fato de LAUREN enxergar nas mais diversas manifestações de militância em defesa de algum direito pessoal, o caráter de direito humano.

By the early 1830 s, references to "human rights" were made by some radical abolitionists and the feminists. However, I am not convinced that references to the "rights of men" and "inherent rights of mankind" did necessarily signify the presence of a human rights conscience. My preference is to use "visions of human rights" only when I can clearly detect the existence of a vision that sees human rights as interdependent and indivisible. ${ }^{13}$

No texto de AFSHARI, percebemos maior preocupação em elucidar o fato de que o exercício dos direitos humanos não pode se dar por compaixão, identidade, dó, ou qualquer outro sentimento dessa sorte. Para ele, a aplicação dos direitos humanos pressupõe uma reflexão sobre o assunto. Ademais, o emprego do termo exige o caráter de consciência de seu conceito.

\footnotetext{
12 MOYN (2010, p. 12) Tradução livre: De todas as confusões conspícuas na busca pelos "percussores" dos direitos humanos, uma tem lugar de destaque. Longe de ser fonte de apelo que transcendeu estado e nação, os direitos assegurados nas primeiras revoluções políticas modernas e prevaleceram desde então eram centrais à construção de estado e nação e não levam a qualquer lugar além até muito recentemente.

13 AFSHARI (2007, p. 12) Tradução livre: Pelo início dos anos 1830, as referências a "direitos humanos" foram feitas por alguns abolicionistas radicais e as feministas. No entanto, não estou convencido de que as referências a "direitos dos homens" e "direitos inerentes da humanidade" que tenham significado necessariamente a presença de uma consciência dos direitos humanos. Minha preferência é a utilização de "visões dos direitos humanos" só quando eu posso claramente detectar a existência de uma visão que enxerga os direitos humanos como interdependentes e indivisíveis.
} 
This recent development in the West constituted the start of a veritable revolution in human affairs where the relationship between the state domination and citizen subordination began to change, and citizens were theoretically required to bestow legitimacy on the state only when its power was perceived to be based on law. ${ }^{14}$

\author{
Além disso, empregar 0 termo direitos humanos \\ indiscriminadamente seria resultado de leviandade por parte do locutor, uma vez que \\ se trata de um advento que veio para revolucionar a história da humanidade.
}

And if we connect them in a linear evolutionary narrative to human rights, we may in fact create a context within which we may not fully appreciate the truly unique and revolutionary notion of the contemporary human rights. ${ }^{15}$

AFSHARI não acredita que o conceito de direitos humanos como algo complexo venha para segregar algumas nações das outras, em função de sua posição na escala de pensamento em relação aos direitos humanos. Pelo contrário, ele pensa que a admissão de tal parâmetro terminaria por integrar essas nações, pois a única forma de passar dessas sociedades menos complexas às mais complexas seria por meio da inclusão. E só assim haveria uma real inclusão.

More particularly, it is possible to relate the concept of subjective rights to the transition from a stratified to a functionally differentiated society with the help of the sociological principle inclusion. Inclusion is the social mechanism by which social systems take human beings to account, that is, constitute human beings as accountable actors, as persons. We shall see that the form of inclusion changes with the transition to modern society and that this has far-reaching consequences for the semantics of law. ${ }^{16}$

Once this commitment reached some of its declared goal, it did not necessarily result in a heightened sense of responsibility to protect, in any meaningful way ways, the human rights of the newly liberated citizens. ${ }^{17}$

Em relação ao debate acerca de os direitos humanos pertencerem a uma categoria que não de direitos constituídos por determinada expressão

\footnotetext{
14 AFSHARI (2007, p. 06) Tradução livre: Este desenvolvimento recente no Ocidente constituiu o início de uma verdadeira revolução nas relações humanas, onde a relação entre a dominação do Estado e subordinação do cidadão começou a mudar, e os cidadãos eram teoricamente necessários para outorgar legitimidade ao Estado somente quando seu poder foi percebido como baseado em lei.

${ }^{15}$ AFSHARI (2007, p. 02) Tradução livre: E se nós os conectarmos em uma narrativa linear evolutiva aos direitos humanos, podemos de fato criar um contexto no qual nós não poderemos apreciar plenamente a noção verdadeiramente única e revolucionária dos direitos humanos contemporâneos.

${ }^{16}$ VERSCHRAEGEN (2002. pp. 265) Tradução livre: Mais particularmente, com auxílio do princípio sociológico da inclusão, é possível relacionar o conceito de direitos subjetivos à transição de uma sociedade estratificada à uma funcionalmente diferenciada. Inclusão é o mecanismo social pelo qual os sistemas sociais consideram os seres humanos, isto é, constitui os seres humanos como atores contabilizáveis, como pessoas. Veremos que a forma de inclusão se modifica com a transição para a sociedade moderna e isso possui conseqüências de amplo alcance para a semântica do direito.

17 AFSHARI (2007, p. 53) Tradução livre: Uma vez que este compromisso alcançou alguns dos seu objetivos declarados, isso não necessariamente resultou em um elevado senso de responsabilidade de proteger, de qualquer maneira significativa, os direitos humanos dos cidadãos recém-libertados.
} 
normativa, mas de direitos já existentes, percebemos que tal característica não é exclusiva dos autores de correntes abrangentes.

Luhmann, citado na obra de VERSCHRAEGEN, acredita serem os direitos dessa natureza preexistentes à sua positivação: "Constitutional and human rights are not a creation of the Law, but are pre-legal as a social institution, as a selfprotecting device of society." ${ }^{18}$

Todavia, tal posição se diferencia do primeiro grupo ao passo que não concebe tais direitos como intrínsecos ao indivíduo. Assim o é por não considerar possível o surgimento dos direitos humanos sem que se constituísse a sociedade moderna, Luhmann os enxerga como um produto dessa.

18 VERSCHRAEGEN (2002. p. 263) Tradução livre: direitos humanos e constitucionais não são uma criação do Direito, mas sim pré-legais como instituição social, como artefatos auto-protetores da sociedade. 


\section{A Declaração Universal dos Direitos humanos das Nações Unidas}

\subsection{O contorno de Direitos Humanos Universais}

Dos marcos comuns a todos os pesquisadores da história dos direitos humanos, dois estão presentes em todas as doutrinas, quais sejam: as revoluções que inauguram o mundo moderno e a DUDH.

Sobre as revoluções, há alguma divergência entre os autores, pois alguns consideram a revolução inglesa ao passo que outros a renegam e somente consideram as revoluções francesa e americana.

Não sendo essa distinção de grande relevância para o trabalho, optamos por considerar a conformação moderna a partir das duas revoluções consensuais e sobre esse ponto desenvolver o raciocínio da concomitância com a emergência do conceito atual dos direitos humanos.

No que diz respeito às revoluções, foram elas que inauguraram a forma de pensar do Estado moderno e moldaram o atual conceito de direitos humanos.

Para os autores de ambas as linhas, esse marco não pode ser ignorado. Para os restritivos, esse é o primeiro momento em que se pode empregar corretamente o termo direitos humanos, ao passo que para os abrangentes é este o evento que inicia a atual conformação do conceito.

Antes desses eventos, desde o final do século XVIII, pensadores socialistas liberais e conservadores implementaram o debate acerca do caráter abstrato e absoluto dos direitos humanos. Dentro desse debate, pretendiam demarcar os limites para seu exercício. Ao fim da discussão, concluíram que o conceito deveria se relacionar com a sociedade na qual seriam exercidos, justamente em decorrência das fronteiras da soberania estatal em face do Direito Internacional.

As revoluções do século XVIII foram as responsáveis por realizar a característica da universalidade para a configuração dos direitos humanos. Essa característica aportou modificações justamente na percepção do papel do Estado cujo cerne foi a questão de que:

De um lado, de fato, o Estado e o Direito repousam em fundamentos nacionais e a sociedade internacional é concebida como uma sociedade de Estados. Mas, do outro, subsiste a idéia romano- 
canônica de uma soberania universal e de um ius comune aplicável a toda a humanidade. ${ }^{19}$

O recorte moderno dos direitos humanos, aquele que é capaz de fazer se encontrarem as doutrinas abrangente e restritiva, é justamente baseado na questão da universalidade. É o último parâmetro a ser agregado à concepção atual de direitos humanos.

Dessa forma, começa a emergir um ideal de direito que transcenderia as fronteiras do Estado. Um direito comum a todos os seres humanos. E a maior conquista da universalidade, não perceptível de plano, é o fato de que os direitos passam a ser, inclusive, oponíveis aos Estados, resguardando integralmente a condição humana.

O Estado assume uma conformação totalmente distinta da empregada anteriormente. A partir dessa conjuntura, não só deve o Estado resguardar os direitos dos cidadãos, como está sujeito a sanções caso não o faça. Sobre esse ponto, LUÑES traz uma consequência bastante interessante da distinção entre direitos humanos e direitos fundamentais:

De esta distinción se desprende que no todos los derechos humanos son objeto de una recepción en los ordenamientos jurídicos estatales, ni siquiera en los Estados de derecho. Es más, incluso los derechos humanos reconocidos como derechos fundamentales pueden gozar de distintos mecanismos de garantías. Por eso, el carácter de la universalidad se postula como condición deontológica de los derechos humanos, pero no de los derechos fundamentales. ${ }^{20}$

Isso demonstra justamente que a concepção de direitos humanos, a qual já existia nos contextos nacionais, agora passa a figurar no âmbito internacional com outra conformação, mais ampla. Os direitos fundamentais seriam aqueles garantidos pelas Constituições, mas que aos direitos humanos seria conferido um status supraconstitucional, daí o caráter universal deontológico do termo.

\footnotetext{
${ }^{19}$ SUPIOT (2007, pp. 239-240)

20 LUÑES (2002, p. 43) Tradução livre: A partir dessa distinção se depreende que nem todos os direitos humanos são objeto de recepção nos ordenamentos jurídicos estatais, nem sequer nos Estados de direito. Além disso, os direitos humanos reconhecidos como direitos fundamentais podem gozar de distintos mecanismos de garantias. Por isso, 0 caráter da universalidade se postula como condição deontológica dos direitos humanos, mas não dos direitos fundamentais.
} 


\subsection{Contexto Histórico e Rascunhos}

De forma a situar a DUDH no contexto histórico de sua apresentação, podemos fazê-lo de duas principais formas, sendo a segunda subsidiária à primeira.

A primeira maneira seria a mais corrente dentre os acontecimentos no curso da história, qual seja, fazer uma análise dos fatos concomitantes a seu surgimento e a consideração prévia de um segundo grupo de fatos que the deu ensejo, de cunho meramente cronológico.

A segunda forma é peculiar a documentos de direito internacional e serve de subsídio àquela em que há a análise conjunta dos fatos. Isso porque mais do que inserir o documento em um período histórico, dessa auto-referência não só se podem extrair quais foram seus objetivos, bem como permite concluir os fatores delimitantes, dentre os do período histórico, os quais permitiram seu surgimento.

Diante dessa realidade, pode-se dizer que a Declaração surgiu de um período confrontado pela experiência da guerra em proporções jamais antes experimentadas. Ela surge como resposta à tentativa hegemônica etnocentrista empreendida nos campos de concentração, à utilização de armas de destruição em massa, às manifestações explícitas de racismo, colonialismo, hegemonia cultural e de povos.

Nesse sentido, fez-se imperativa a manifestação em defesa dos direitos humanos, os quais passaram a figurar como pauta significativa de todas as discussões internacionais.

Por certo, de uma análise mais aprofundada, percebe-se que a despeito da tentativa de assimilar a declaração a um período específico, os Estados que aprovaram-na ainda estavam imbuídos de ideias provenientes do período pósguerra, contribuindo para a redação das cláusulas. Um exemplo externo a esse diploma, mas que sugere essa tendência, é a própria Convenção de Prevenção e Punição do Crime de Genocídio, aprovada em dezembro do mesmo ano.

Dessa forma, a sucessão de acontecimentos levou à adoção deliberada de um instrumento inicialmente simbólico de combate aos abusos perpetrados no período imediatamente anterior. 
There's an honored tradition, both in Europe and elsewhere, of regarding "rational outlook," the "spirit of science" and of "free enquiry" as "constituting the progressive" aspects of modernity.

No que tange à redação de uma Declaração Universal de Direitos Humanos, ao passo que nos impulsiona a ideia de uniformização dos mais nobres aspectos da coletividade enquanto indivíduos, surgem dúvidas acerca da viabilidade do projeto.

A problematização surge nas mais diversas searas, a começar pelos próprios termos empregados no título: Declaração Universal dos Direitos Humanos.

A primeira questão que se aponta seria a da necessidade de definição conceitual concreta de direitos humanos, para que deles se pudesse pleitear alguma tutela. Contudo, observa-se que, ainda no tempo presente, tal delimitação representa por si só um desafio ao corpo acadêmico encarregado do estudo dos direitos humanos. Esse desafio emerge, pois o conceito em questão se relaciona com a natureza do instituto e, para a grande maioria da comunidade, essa natureza, por sua vez, possui influência direta do contexto histórico de seu surgimento, um dos maiores debates da atualidade, como pudemos observar no primeiro capítulo.

O ano de 1948 foi marcado por intensas reflexões sobre o que seria a Declaração Universal dos Direitos Humanos. Ao longo de todo o ano, esforços foram empreendidos para que se obtivesse a melhor redação do documento final. Para tanto, identificam-se um sem número de projetos e suas respectivas emendas.

Nesse interregno, igualmente preocupada com a eficácia de um documento dessa magnitude, a UNESCO encomendou a diversas personalidades do direito internacional à época um manuscrito provisional denominado "A collective approach to the problems of Human Rights"22. Tratava-se de uma consulta a problemas filosóficos aportados pela publicação de uma declaração pretensamente universal concernente aos direitos humanos.

A questão da universalidade tanto da DUDH bem como do próprio conceito de direitos humanos é alvo de diversas discussões acadêmicas e foi abordada no item anterior.

\footnotetext{
${ }^{21}$ CHAKRABARTY (2000, p. 237) Tradução livre: Há uma honrada tradição, tanto na Europa como nos demais lugares, de perceber a "visão racional", o "espírito da ciência" e de "inquisição livre" como "constituintes dos progressivos" aspectos da humanidade.

${ }^{22}$ Tradução livre: Uma abordagem coletiva aos problemas dos Direitos Humanos
} 
É interessante notar que, ao contrário do que se pode pensar à primeira vista, é justamente o caráter generalista da Declaração que confere identidade com todo e qualquer cidadão do planeta.

Such rights as freedom of speech, conscience, religion, and association do not only protect a sphere of personal autonomy, but they also guarantee the capacity to develop a social identity. ${ }^{23}$

Finally, identities do not result merely from individual choice, but form relational activities among a group of people united to achieve a common purpose in the form of a movement. ${ }^{24}$

Como aduzido anteriormente, a apresentação universal da DUDH também pretendia que tal Declaração se perpetuasse no tempo.

A empreitada em produzir um escrito que superasse as limitações temporais pode ser observada em um de seus rascunhos, o de junho do mesmo ano, no qual havia menção expressa à Segunda Grande Guerra. O corpo de redatores houve por bem retirá-la, em virtude da intenção de que o documento se perpetuasse, se não pela eternidade, por tanto tempo quanto fosse possível.

Já na versão atual, pode-se observar que, quando há menção ao passado, esta é feita de maneira muito mais abstrata. Isso ocorre justamente com o intuito de não permitir identificação direta com algum período em questão, ressaltando a intenção do documento de perdurar através dos tempos.

\footnotetext{
${ }^{23}$ VERSCHRAEGEN (2002. pp. 274) Tradução livre: Direitos como a liberdade de expressão, de consciência, de religião, e de associação e não apenas protegem a esfera da autonomia pessoal, mas também garantem a capacidade de desenvolver a identidade social.

24 RAJAGOPAL (2003, p. 417) Tradução livre: Por fim, identidades não resultam meramente de escolha individual, mas de atividades relacionais entre um grupo de pessoas unido para atingir um propósito comum na forma de um movimento.
} 


\section{O PERÍodo Pós-DeclaRAÇÃo de 1948 E AS VISÕES de DiReitos Humanos}

\subsection{Perspectiva da Periodização}

No capítulo 2, analisamos a DUDH situando-a em seu contexto histórico com ênfase para os fatos históricos que possibilitaram seu surgimento, ou seja, o impacto que a conjuntura teve em relação ao documento.

Tomando por base a construção supracitada, o que se pretende aqui é tomar o sentido inverso, não com o objetivo de desconstruir as possibilidades traçadas quando da inserção da influência da situação global na escritura, mas sim de analisar a influência que teve a Declaração de 1948 na história da humanidade, sobretudo no que tange ao direito internacional, com ênfase para os direitos humanos.

Essa ferramenta aqui utilizada é a chamada "periodização". Trata-se de análise historiográfica com o viés de se observar o todo sob a óptica de determinado acontecimento.

A eleição de determinado fato em detrimento de outros não é aleatória, e tem por consequência denotar certa tendência política daquele que assim o faz.

Ocorre que, para se produzir a análise histórica a partir da perspectiva da periodização, é necessário que sob o ponto de vista lógico sejam perceptíveis as mudanças que tal acontecimento tenha acarretado no cenário em observância. Sobre a periodização no direito internacional, tratada por LESAFFER, temos que:

Periodisation is at the best of times an occupational hazard of the historian. It is an exercise in generalization and forces the historian to make stark choices. The historian has to single out these trends and events that sustain claims to the internal consistency of the historical epoch; he or she has to underplay those that contradict that consistency. Furthermore, the historian has to highlight the discontinuities with the epochs before and after. Often, temptation is there to elevate a single event to an epochal event, a historical caesura that marks the beginning and end of an epoch. ${ }^{25}$

\footnotetext{
${ }^{25}$ LESAFFER (2010, p. 01) Tradução livre: Periodização é na melhor das hipóteses um risco ocupacional do historiador. Tratase de um exercício em generalização e força o historiador a fazer escolhas resolutas. O historiador tem que destacar essas tendências e eventos que sustentam queixas à consistência interna do período histórico; ele ou ela tem de contornar aquilo que contradiz a consistência. Além do mais, o historiador tem de elucidar as descontinuidades entre as épocas anterior e posterior. Frequentemente, a tentação atua no sentido de elevar um evento singular à condição de evento épico, uma cisão histórica que marca o início e o fim de uma época.
} 
Nesse sentido, por vezes, tamanha é a força depreendida no sentido do reconhecimento das mudanças observadas e do impacto ocasionado pelo objeto que parece não nos restar outra opção que não a periodização a partir de certo fato histórico.

Sobre isso, há que se adotar muita cautela. Isso porque, em geral, são notáveis as influências exercidas quando da análise de um ato histórico que se elege para a consideração da periodização. Vale dizer que, em muitos dos casos, até mesmo para a comunidade acadêmica há consenso sobre a importância do evento escolhido. Contudo, há que se observar a determinação política por trás de tal opção.

Não é a circunstância de a maioria dos teóricos tratar com segurança a importância de dado fato na história que afasta a conotação política que essa escolha teve e, mais profundamente, continua a perpetrar em determinado nicho.

As periodizações servem para tornar pensáveis os factos. Mas, no caso de periodizações da história universal, de que aqui tratamos quase exclusivamente, elas não desempenham este papel apenas para satisfazer exigências puramente intelectuais e desinteressadas. $^{26}$

Em sentido similar:

Periodization as I address to it, then, does not refer to a mere backdescription that divides history into segments, but to a fundamental political technique - a way to moderate, divide, and regulate - always rendering its services now. In an important sense, we cannot periodize the past. ${ }^{27}$

A validação de certa conduta histórica não é despretensiosa. Como se observa, não há uma necessidade histórica em si de elevar determinados argumentos à condição distinta dos demais. Trata-se, sobretudo, de demanda social ou quiçá pessoal em que a predileção reflete um objetivo, por vezes implícito.

Cumpre ressaltar que a orientação política não reside somente na escolha do fato próprio, mas se perpetua ao passo que esta projeta retamente o que se pretende nos dias atuais com a divisão do passado da forma como foi implementada.

\footnotetext{
${ }^{26}$ POMIAN (1993, p. 209)

27 DAVIS (2008, p. 05)
} 
...os enunciados dum discurso de periodização estão sempre ligados entre eles por uma sintaxe que traduz a concatenação das formas. Trata-se, com efeito, de um discurso que responde a numerosas questões, que fala das causas do aparecimento $e$ do desaparecimento das formas ou da sua evolução, da passagem de uma forma a outra forma, da orientação geral do processo, das relações entre duração e mudança, contínuo e descontínuo, etc. ${ }^{28}$

Quando deslocada do pólo teórico para a cognição do resultado no aspecto prático, além da esfera política em termos de dinâmicas de implementação, há que se considerar o resultado na esfera jurídica, não menos distante e nem isenta da escolha do argumento que ocasionará a divisão do período histórico estudado sob a perspectiva da periodização.

[...] the history of periodization is juridical, and it advances through struggles over the definition and location of sovereignty. ${ }^{29}$

O extrato acima foi retirado de uma obra que trata a questão da periodização no contexto de transição da idade média. A parte que nos interessa observar é a que conclui que o enaltecimento de determinado evento é responsável por deslocar o conceito tanto em substância quanto em temporalidade.

Considerar a DUDH como marco que inaugura os direitos humanos modernos atrela a ela, necessariamente, um significado específico de direitos humanos.

Sob o ponto de vista do conceito em si, essa opção não é tão problemática. O fato de a DUDH não fazer previsão expressa ao conceito de direitos humanos agrada tanto aos que consideram o conceito como algo dinâmico como aqueles que o consideram como algo auto-evidente.

No primeiro caso, é compatível com a visão dos direitos humanos como algo dinâmico que não se atribua significação fechada e o conceito possa se alterar de acordo com as demandas da comunidade. Para aqueles que confiam nos direitos humanos como um ente inerente aos indivíduos socialmente agrupados, a dinâmica parece atuar na mesma medida ao passo que eles dispensam a necessidade da constituição formal do conceito.

Além disso, como trataremos adiante, os direitos humanos possuem uma carga semântica muito forte, que vincula a interpretação e, embora

\footnotetext{
28 POMIAN (1993, p. 209)

29 DAVIS (2008, p. 06)
} 
encontremos alguns entraves, não deixam espaço de conforto para que um Estado ou ente a eles se oponha.

Superada a questão de a amarra do conceito de direitos humanos à DUDH não modificar o conceito em si, cumpre ressaltar que o que se evidencia é justamente a opção política por trás do documento, noção essa que acaba justamente por aportar o debate da localização espaço-temporal e de significação dos direitos humanos, contemplada pelo embate entre as linhas restritiva e abrangente.

O autor LESAFFER propõe uma análise sobre a questão da periodização no Direito Internacional e as apresenta em três tipos ${ }^{30}$. Apesar de se tratar de uma visão histórica do Direito Internacional propriamente dito, as visões parecem coincidir com aquelas que se têm dos direitos humanos pelos internacionalistas, de forma que podemos empreender uma analogia com base em seus elementos. A primeira seria correspondente à perspectiva abrangente e as duas últimas em conjunto representariam a perspectiva restritiva.

De início, encontramos a corrente que seria sugerida por diversos historiadores alemães e por eles denominada "hegemonic approach" ${ }^{31}$. Em tal perspectiva, o Direito Internacional seria ditado pelo poder predominante no período em questão e teria seu pólo deslocado de acordo com a mudança do detentor da hegemonia.

Sobre esse sentido, a corrente se aproxima da perspectiva abrangente. Em cada momento, uma civilização diferente em razão de seu contexto contribui com um acontecimento que desloca o eixo principal de percepção dos direitos humanos ou da detenção hegemônica.

Até mesmo a controvérsia em relação ao momento que primeiro se observa tal dinâmica pode ser encontrada na abordagem dos dois assuntos. Há quem defenda que a hegemonic approach tenha surgido na idade média. Entretanto, pelas explicações que se seguem, seria inclusive possível que se considerasse como berço do Direito Internacional as civilizações clássicas. Não muito diferente é a discussão encontrada sob a óptica dos direitos humanos, na qual se pode observar que mesmo dentro do grupo dos abrangentes o assunto não é consensual.

\footnotetext{
30 LESAFFER (2010, pp. 02-07)

${ }^{31}$ Tradução livre: abordagem hegemônica
} 
A visão seguinte seria aquela que considera o Direito Internacional moderno como surgido na Europa e propagado pelo resto do mundo, para então se tornar um "universal system of law"32. A essa abordagem, como a ideia sugere, foi concedida a nomenclatura "Eurocentric approach."33

Por seu turno, essa visão é bastante compatível com a ideia do surgimento dos Direitos Humanos segundo o conceito "ocidental", o qual mais bem pode ser entendido como europeu.

Por essa percepção, pode-se traçar um paralelo entre o modelo eurocêntrico para análise do direito internacional e o modelo de direitos humanos que acredita nessa mesma dinâmica geográfica para disseminação desses direitos. Para ambos os casos, as ideias teriam seu embrião na Europa cristã, seguida dos Estados Unidos, primeiras colônias a se tornarem independentes, para só depois atingir o resto do mundo. Mas sempre adstrita à perspectiva europeia.

O terceiro tipo seria aquele denominado "state-centric"34 e é reconhecido como o mais fundacional. Consideram o direito internacional como produto do processo evolutivo o qual concebeu a soberania estatal, processo esse que teria tido início também na Europa. Essa postura guarda relação com aqueles que acreditam que os direitos humanos tomaram tal conformação em função das declarações inglesa, francesa e até a americana.

Tomando por base a concepção estado-centrista, percebe-se que apesar de não aportar essa consciência no nome, a acepção também termina por ser eurocêntrica ${ }^{35}$. A diferença é que enquanto no modelo eurocêntrico se observa um local em função de suas práticas para determinar o surgimento do direito internacional, no modelo estado-centrista se presume um instituto para que se desempenhe a "evolução" do que se tem por direito internacional, o qual, por coincidência ou não, tem a mesma raiz geográfica.

Paralelamente ao fato de que o posicionamento dos conceitos pode depender do argumento histórico escolhido, também a periodização nos informa sobre o momento presente, uma vez que a escolha pela localização no passado de

\footnotetext{
32 LESAFFER (2010, p. 03) Tradução livre: sistema universal de direito

33 Tradução livre: abordagem eurocêntrica

34 Tradução livre: estado-centrista
}

35 Apesar de o termo somente se referir à Europa, para melhor entendimento podemos acrescentar os EUA e fazer uma analogia com o apreço pelo termo "ocidental" empregado pelos teóricos restritivos dos direitos humanos. Ressalte-se que nem Europa, nem Ocidente se referem corretamente ao que se pretende dizer. No primeiro caso, por não abarcar todas as implicações e no segundo por fazer o inverso, incluir na noção nações que nada tiveram a ver com o tema tratado. 
determinados fatos reflete a mentalidade atual, sobretudo por meio dos dilemas políticos atuais.

É o mesmo que dizer que o enfoque que se dá a certo acontecimento do presente ou passado reflete uma vontade de repercussão deste no futuro. Isso é recorrente pela utilização da ferramenta histórica. Esta, que antes tinha por objetivo perfazer profecias sobre o futuro, ainda hoje tenta absorver certa repetição de comportamentos, uma vez que o futuro poderia ser conhecido a partir de uma reflexão sobre o passado e o presente.

Nessa seara, é possível concluir que a tentativa de periodizar um período histórico ainda vigente pode ser bastante problemática, uma vez que não muito se poderia concluir nem a respeito do passado nem do futuro.

Diante do mesmo dilema, quando indagado com que se relacionam as condições que tornam possíveis uma história cumulativa, POMIAN, referindo-se a Lévi-Strauss, assim se manifestou:

\begin{abstract}
Propondo um remédio, Lévi-Strauss, com um escorregamento constatável em todos quantos antes dele se preocuparam com a periodização da história universal, passa dum discurso científico a uma exortação a propósito do futuro: a humanidade deve cumprir o seu <sagrado dever> de evitar, por um lado, o aprisionamento das culturas nos seus particularismos e, por outro, a imposição a todas do mesmo modo de vida. ${ }^{36}$
\end{abstract}

Sobre esse aspecto cabe a indagação se a formulação do conceito dos direitos humanos se situa na história de um período vigente ou se a DUDH foi de fato o argumento que encerrou tal pretensão.

Como quiera que estamos asistiendo al ataque "posmoderno" contra el proyecto moderno de la llustración, se hace inevitable indagar hasta qué punto el Estado de Derecho y los derechos humanos, en cuanto ideales de la modernidad, mantienen su vigencia o han devenido obsoletos, o, en todo caso, si deben ser objeto de una revisión que elucide su sentido actual. ${ }^{37}$

Sabendo que a técnica da periodização não pode ser aplicada a um período histórico ainda vigente, para saber se podemos aplicá-la no caso em questão devemos fazer a análise do conceito de direitos humanos sob a óptica da

\footnotetext{
36 POMIAN (1993, p. 201)

37 LUÑES (2002, p. 17) Tradução livre: Uma vez que estamos testemunhando o ataque "pós-moderno" ao projeto moderno do lluminismo, é inevitável para investigar em que medida o Estado de direito e direitos humanos, como os ideais da modernidade, ainda em vigor ou se tornaram obsoletos, ou em qualquer caso, se devem ser objeto de uma revisão que elucide seu significado atual.
} 
obsolescência. Ou seja, na linha do argumento proposto acima, precisamos verificar se no momento atual o conceito de direitos humanos está estável ou carente de revisão. Caso estivesse carente de revisão, significaria que estaríamos no intercurso do período de estabilização e, portanto, o conceito não estaria fechado e não poderia ser analisado pela periodização. Contudo, o conceito parece estar bastante atualizado com suas pretensões, o que permite que nos valhamos da ferramenta da periodização.

Nessa concepção, percebemos a aplicação prática de se analisar os direitos humanos sob a perspectiva histórica, da maneira mais fidedigna quanto for possível, para que se possam extrair os melhores resultados.

The true history of human rights matters most of all, then, in order to confront their prospects today and in the future. ${ }^{38}$

Se o objetivo de se estudar a história dos direitos humanos é aquele de perceber seus prospectos tanto no presente como no futuro, a forma mais comprometida de fazê-lo - caso o argumento adotado seja o da periodização - é elegendo os prováveis eventos mais impactantes à conformação dessa história. A perspectiva da periodização não oferece uma análise meramente linear, preconiza os acontecimentos realmente marcantes. É a adoção da visão do passar do tempo sob o viés qualitativo em detrimento do quantitativo.

La superposition du temps quantitatif au temps qualitatif engendre une autre série de problèmes non dans la métrologie cette fois mais dans la vie quotidienne... ${ }^{39}$

Dentro dessa concepção, levando em conta o fato de que, qualquer que seja a visão adotada, a DUDH é onipresente e tem sua importância elevada ao fato de que é, indubitavelmente, o documento contemporâneo mais importante para o Direito Internacional dos Direitos Humanos, é possível que a análise dessa peça em muito tenha para contribuir com a visão atual dos direitos humanos, bem assim com suas projeções futuras.

\footnotetext{
${ }^{38}$ MOYN (2010, p. 09) Tradução livre: À verdadeira história dos direitos humanos interessa acima de tudo, então, o objetivo de confrontar seus prospectos agora e no futuro

${ }^{39}$ POMIAN (1984, p. 232) Tradução livre: A superposição do tempo quantitativo ao tempo qualitativo engendra uma outra série de problemas não na meteorologia dessa vez, mas na vida cotidiana...
} 


\subsection{Disparidade entre os sujeitos da norma}

Em relação à disparidade quando da análise dos direitos humanos, percebemos que ela não se dá somente entre os sujeitos da norma, mas também entre a previsão legal e sua implementação:

One of the main issues that the current historiography has to grapple with is the apparent disparity between the often-celebrated normative global achievements in the codifying human rights values among the UN member states and the often-lamented failures to enforce them. ${ }^{40}$

Na primeira parte do trabalho, quando tratamos das duas correntes de conceituação de direitos humanos, informamos que a adoção de uma em detrimento da outra traria consequências práticas para a conjuntura atual da história dos direitos humanos, sobretudo em relação ao posicionamento da DUDH nela. Isso não no sentido de localizar a Declaração no calendário gregoriano, mas pela alternativa que nos sugere a perspectiva da periodização, em que a opção por uma visão é capaz de deslocar com ela outras entidades conceituais.

O terreno de elucidação do aspecto prático do documento em análise seria a questão que permeia qualquer tentativa de elaborar um documento dessa magnitude: a de sua viabilidade.

As demandas que são levadas em conta desde a sua elaboração, quando de sua promulgação se concretizam, inafastavelmente, por dois pontos principais: (i) se o conteúdo ali contemplado faz sentido para as populações que pretende atingir; (ii) se uma vez compreendida a semântica, os atores seriam capazes de implementá-la.

Essa discussão nada mais é do que a recorrente análise de legitimidade e eficácia da DUDH. Essa abordagem é típica de tratados, cuja natureza se distancia um pouco daquela da Declaração. Contudo, torna-se cabível em decorrência da atribuição do caráter de jus cogens e elevação de seu status a norma internacional em decorrência dos costumes no direito internacional.

Feitas essas considerações, passamos ao exame desses dois institutos que garantiriam a materialização dos direitos lá previstos.

\footnotetext{
40 AFSHARI (2007, p. 01) Tradução livre: Uma das maiores questões da historiografia atual é lidar com a aparente disparidade entre as frequentemente celebradas conquistas normativas globais em codificar valores dos direitos humanos entre os Estados membros da ONU e as frequentes lástimas nos fracassos de fazer com que elas sejam cumpridas.
} 
Por questões didáticas, a ordem dos quesitos será invertida e nos ateremos inicialmente à apreciação da questão da eficácia do documento.

Para que se realize um estudo sobre sua eficácia, um possível caminho a ser seguido seria o da aplicação paralela à lógica das incorporações dos tratados internacionais, quando for passível de analogia à DUDH. Para tanto, elencaremos as principais propostas de incorporação ideológica dos tratados internacionais presentes na teoria das relações internacionais.

Uma perspectiva neorealista ${ }^{41}$ das relações internacionais propõe uma divisão baseada em poder, na qual se sugere que as ações serão implementadas no cenário internacional única e exclusivamente se for de interesse das potências internacionais.

Já sob o ponto de vista dos institucionalistas ${ }^{42}$, a cooperação em longo prazo seria o meio para realização conjunta dos ideais no âmbito internacional. Essa corrente pretende ser mais reflexiva, não acredita que um documento por si só é capaz de modificar a visão de algum assunto, mas sim que um novo entendimento pode ser construído a partir dele.

Ambas as visões trariam ao debate a compreensão de uma segunda questão: "whether there are substantial mutual benefits from greater respect for human rights across countries." 43 Mas essa questão do interesse em implementar os direitos humanos consiste num tema de bastante complexidade, o qual merece uma análise posterior, inadequada a esse trabalho.

Uma terceira corrente seria a da teoria dos regimes, ${ }^{44}$ que se beneficia por ser uma especificação da institucionalista, uma vez que confere o status de obrigação aos termos do documento quando de sua ratificação.

Por assim dizer, ao contrário de a vinculação surgir em virtude de uma racionalização histórica, a ratificação do documento como opção política já denota a materialização da vigência do direito em questão.

O modelo de processo legal transnacional ${ }^{45}$ é aquele que preconiza o conteúdo normativo internacional quando da assunção espontânea por meio de

\footnotetext{
${ }^{41}$ NEUMAYER (2005, p. 926)

42 NEUMAYER (2005, p. 927)

43 NEUMAYER (2005, p. 927) Tradução livre: se haveria benefícios mútuos substanciais oriundos de maior respeito pelos direitos humanos através dos países.

44 NEUMAYER (2005, p. 927)

45 NEUMAYER (2005, p. 927)
} 
legislação interna de origem distinta do instituto da ratificação com igual proposta ou ainda a incorporação ideológica por meio de outros atores, ao exemplo de ONGs, diplomatas, entre outros.

A linha liberal ${ }^{46}$, em sentido oposto ao que propõem os neorealistas, abandona a concepção unitária de estado e pressupõe diversos atores com interesses distintos.

A teoria das conexões transnacionais em defesa dos direitos humanos ${ }^{47}$ confia na força de redes de comunicação entre atores internos e externos na área da defesa dos direitos humanos, sobretudo da sociedade civil.

À exceção da teoria dos regimes, a qual aponta necessariamente a questão da ratificação, as demais parecem ser adequadas à analogia com a intelecção do disposto na DUDH pelos diversos direitos internos.

$\mathrm{Na}$ ordem em que foram dispostas, parece contemplar um amadurecimento na questão de assunção das normas sob o ponto de vista da naturalidade de acepção do conceito.

Nas distintas nações do globo, pode-se perceber disparidade entre os métodos empregados. Isso talvez reflita a própria relação de conforto e identidade que cada um desses países possui com as disposições.

Desde el punto de vista jurídico, algunos constitucionalistas al cotejar el Derecho constitucional comparado de la actualidad, comprueban que los derechos y libertades reconocidos en los diversos textos constitucionales difieren notablemente entre sí. Incluso entre los Estados pertenecientes a la cultura occidental, aquellos que obedecen al modelo político del Estado de derecho, sólo reconocen las libertades del signo indicidual, o sea, los derechos personales civiles y políticos; en otros, los que obedecen al modelo del Estado social de derecho, amplían el catálogo de las liberdades para incluir en él también los derechos económicos, sociales y culturales. ${ }^{48}$

É provável que esse mecanismo aprofundado seja, portanto, o melhor meio de análise de eficácia ${ }^{49}$ do conteúdo da Declaração. Sob o ponto de

\footnotetext{
${ }^{46}$ NEUMAYER (2005, p. 930)

47 NEUMAYER (2005, p. 930)

48 LUÑES (2002, p. 34) Tradução livre:

49 O termo eficácia se refere à eficácia de assunção do conceito de direitos humanos tal qual disposto na DUDH e não à eficácia da norma sobre a análise da transgressão. Ou seja, se os destinatários a compreendem como norma vinculadora e não se esta de fato vincula suas ações. Nesse sentido: "A validade de uma norma jurídica não coincide com sua aplicação ao caso particular [...] Aqui a esfera do direito mostra a sua essencial proximidade com aquela da linguagem. Como uma palavra adquire o poder de denotar, em uma instância de discurso em ato, um segmento da realidade, somente porque ela tem sentido até mesmo no próprio não denotar (isto é, como langue distinta de parole: é o termo na sua mera consciência lexical, independentemente de seu emprego concreto no discurso), assim a norma pode referir-se ao caso particular somente porque, na exceção soberana, ela vigora como pura potência, na suspensão de toda referência atual. E como a linguagem pressupõe o
} 
vista das diferenças de implementação nos países, poderíamos reconhecer os pormenores da assunção de seus institutos.

Esse método sai muito à frente da simples consideração numérica dos signatários, por dois motivos principais. O primeiro seria o fato de que a assinatura do documento ocorre por parte daqueles dotados de carta de plenos poderes ou de autoridades no uso da função pública, os quais, independentemente de terem sido ali colocados de forma democrática, não representam fidedignamente a realidade de seus concidadãos. É certo que, sob a égide do direito internacional contemporâneo, os cidadãos são os destinatários principais da DUDH; contudo, pressupor que esses conhecem seu significado somente por serem membros de um dos países signatários é uma perspectiva equivocada. A segunda medida está relacionada ao fato de que qualquer documento internacional que envolva "direitos humanos" deve ser tratado com peculiaridade; não é o fato de um país ter assinado ou não ter se posicionado contrariamente ao documento que ele o legitima integralmente.Tal fato está ligado à própria semântica dos direitos humanos, uma vez que não contribui para uma boa imagem perante o cenário internacional um Estado se opor a eles. No máximo, são admitidas ressalvas e abstenções.

Isso é facilmente perceptível justamente por ocasião de aprovação da DUDH. Dos países integrantes da Assembléia Geral, 48 votaram a favor, oito se abstiveram, dois estavam ausentes, mas nenhum votou contra.

Isso porque, apesar de certos recortes dados pela DUDH sobre os direitos humanos responsáveis por suscitar divergências, nenhum país se sentiu confortável em se opor a eles por meio do voto. Ressalte-se que seis dos países que se abstiveram eram membros da então União Soviética e assim se posicionaram em razão da falta de ênfase no papel do estado. As outras duas abstenções foram por parte da Arábia Saudita e África do Sul, a primeira em função da previsão de igualdade de direitos no casamento e de liberdade para mudar de religião e, a última, por conta da então empreendida política do apartheid.

Em sua obra, DEVINE, HANSEN e WILDE afirmam que a peculiaridade de não ter havido oposições diretas à aprovação da DUDH se deve a

não lingüístico como aquilo com o qual deve poder manter-se em relação virtual (na forma de uma langue, ou, mais precisamente, de um jogo gramatical, ou seja, de um discurso cuja denotação atual é mantida indefinidamente em suspenso), para poder depois denotá-lo no discurso em ato, assim a lei pressupõe o não jurídico (por exemplo, a mera violência enquanto estado de natureza) como aquilo com o qual se mantém em relação potencial no estado de exceção." [AGAMBEN2010 p. 27] 
uma estratégia traçada pelo governo norte-americano, conforme o seguinte fragmento:

A astuta estratégia de Eleanor Roosevelt de dar à Declaração a forma de uma resolução não impositiva da Assembléia Geral fez com que fosse aprovada apesar das profundas divergências entre os países, já que eles não a viam como geradora de obrigações perante o direito internacional. ${ }^{50}$

Atualmente essa não é mais a realidade da vinculação dos países signatários à Declaração. Apesar do inicial caráter não impositivo da declaração, com o advento da assinatura do PIDCP e PIDESC - pactos que adicionados à DUDH formam a Carta Internacional de Direitos Humanos - o conteúdo arrolado na Declaração se converteu em disposições substantivas. Ademais, alguns anos depois de sua promulgação, as disposições da Declaração se tornaram coativas em virtude de seu caráter consuetudinário concedido pela própria prática do direito internacional.

Mudando o foco de análise, essa questão da suposta influência exercida pelos EUA em relação aos demais Estados por meio do artifício da DUDH nos aporta outra questão de enorme interesse, a qual, por sua vez, guarda relação com a questão da legitimidade - que havia sido deixada para tratarmos posteriormente e agora parece o momento oportuno.

Quando focalizado o fato de que a redação da DUDH, que se destina a todos os seres humanos do planeta, coube a apenas um grupo muito seleto em que poucas nacionalidades tinham representação, a dúvida que inevitavelmente surge é em relação a uma possível tentativa de dominação ideológica desse pequeno grupo sobre as demais nações. Aqui nessa cena está presente em peso o recurso às visões restritiva e abrangente dos direitos humanos.

Tomando-se por base a perspectiva da periodização e suas consequências políticas, percebe-se que a possibilidade de manipulação do documento a fim de impor valores culturais, dentre outros mecanismos de poder, é perfeitamente compatível com a crítica trazida pela linha abrangente.

Retomando as distintas visões sobre o conceito de direitos humanos, percebe-se, da análise da concepção abrangente aqui em comento, maior tendência inclusiva às realidades orientais e até mesmo ocidentais

\footnotetext{
${ }^{50}$ DEVINE, HANSEN, WILD (2007, p. 89)
} 
subdesenvolvidas. Apesar de pertencerem ao grupo dos abrangentes, tal característica não é percebida na obra de DEVINE, HANSEN e WILD, que somente é inclusiva em relação à ausência de barreira temporal para a elucidação do conceito de direitos humanos.

Em sentido oposto, encontram-se os restritivos, que possuem uma abordagem menos inclusiva. Por classificarem os direitos humanos como algo bastante ocidental, consideram-nos inadequados à aplicação ao oriente.

Quando da encomenda da UNESCO da "inquiry on human rights", ao internacionalista LASKI coube a análise da questão de uma declaração universal dos direitos humanos, tendo ele chegado à seguinte conclusão:

Nothing, in fact, is gained, and a great deal may be lost, unless a Declaration of this character notes the fact of important ideological differences between political societies and takes full account of their consequences in the behavior both of persons and institutions. ${ }^{51}$

Portanto, uma declaração que pretende universalizar valores tem de estar bastante atenta a todas as diferenças ideológicas entre seus destinatários. Somente assim, a pretensão de universalizar pode alcançar um propósito positivo.

Um autor controverso da filosofia do direito, Michel VILLEY, declara seu ceticismo em razão da promulgação da DUDH, como se fosse somente um meio de dominação norte-americana.

Não voltaremos ao que tem de etnocêntrico - e de utópico - o sonho de universalizar o way of life americano: o regime das eleições livres das democracias chamadas ocidentais não parece exportável a Uganda. Nem aos vícios do regime igualitarista virtualmente contido nos direitos humanos: tornar as mulheres juridicamente idênticas aos homens, os bebês às pessoas idosas, e os pobres aos ricos seria destruir a riqueza do mundo e sua variedade; um triunfo da entropia. Talvez os votos do socialismo vão nesse sentido. É, antes, o resultado contrário que eu esperaria da arte jurídica. ${ }^{52}$

Independentemente de aceitação de seu argumento pela comunidade acadêmica, posicionamentos dessa natureza acabam por cumprir um papel de chamar a atenção para algo que pode estar realmente ocorrendo.

Quienes con razón advierten del peligro de hipostasiar la universalidad para convertirla en una mera justificación de intereses

\footnotetext{
51 LASKI (1948, p. 06)

52 VILLEY (2007, p. 07)
} 
políticos, o en una pantalla encubridora de discriminaciones o desigualdades fácticas, han contribuido en forma muy positiva a clarificar el discurso actual sobre la universalidad. ${ }^{53}$

Por vezes, essa consequência não decorre de uma vontade de dominar os outros povos pura e simplesmente em razão do poder. Mas pode acontecer de se exaltar tanto determinados ideais como os direitos humanos e sua universalização que a tentativa de seu compartilhamento pode acabar virando uma forma de imposição. Converge nesse sentido o trecho abaixo:

\begin{abstract}
Não há dúvida de que tanto a Revolução Francesa como a Russa pretendiam libertar toda a humanidade e ambas encontraram no estrangeiro uma audiência muito vasta. Mas mal os primeiros ímpetos esmoreceram, tornou-se claro que estas pretensões, inscritas nas cronosofias e nas cronologias limitam-se a justificar a dominação de um estado sobre os outros.
\end{abstract}

Pelo fragmento, observa-se que não basta uma vontade do legislador em universalizar valores com objetivos maiores: as condições fáticas têm de contribuir para o resultado.

Ao analisar determinados aspectos, às vezes contribuímos equivocadamente para o fato de que tais condições seriam favoráveis.

Ao analisar a conduta de alguns países do Oriente, sobretudo em consideração à política externa por eles empreendida, temos a errônea impressão de que estes estariam assumindo o modelo jurídico empregado pelo Ocidente.

Contudo, com uma análise mais aprofundada, conclui-se que a adoção de tal estratégia somente ocorreu com o intuito de viabilizar as negociações com os países do Oeste, uma vez que quando observados os parâmetros jurídicos internos, pouca ou nenhuma diferença se observa em relação aos padrões tradicionalmente adotados.

No caso da legitimação dos direitos humanos tal como previstos na DUDH, o processo extrapola a utilização de ferramentas com o objetivo de tornar possíveis as transações. Trata-se de questão normativa que necessita de valoração moral, tornando o objeto muito mais complexo.

\title{
A complexidade do objeto, entretanto, não subentende
}

\footnotetext{
53 LUÑES (2002, p. 44) Tradução livre: Aqueles que com razão advertem do perigo de menosprezar a universalidade para convertê-la em uma mera justificativa de interesses políticos ou em uma tela para encobrir discriminações e desigualdades fáticas têm contribuído de maneira muito positiva a esclarecer o atual discurso sobre a univeralidade.

${ }^{54}$ POMIAN (1993, p. 166)
} 
necessariamente a dominação ideológica de certos povos por aqueles que elaboraram o documento. Essa é apenas uma corrente de pensamento que emerge em oposição à visão restritiva.

Contudo, VERSCHRAEGEN percebe uma alternativa ao argumento sob o ponto de vista de Luhmann:.

By, for instance, institutionalizing religious freedom and freedom of conscience, modern society prevents the continuous interference of religion and politics. ${ }^{55}$

Com a perspectiva concedida pelo fragmento acima, assume-se que não seria possível a interferência a Declaração. Assim, funcionaria como remédio aos recursos de opressão das duas realidades.

Seria mais um mecanismo de auto-regulação sugerido por Luhmann. Sobre esse aspecto, se, de fato, as coisas ocorrerem como sugere o fragmento, ambos sistemas estarão resguardados do abuso do outro. Por um lado, o oriente e os países do sul temem a subjugação aos países desenvolvidos do oeste, ao passo que, em contrapartida, os países ocidentais não deveriam temer o fanatismo religioso.

In fact, systems theory distinguishes different types of society on the basis of the dominant (not the only or exclusive) form of internal societal differentiation, or the way subsystems are built up within the encompassing social system called society. [...] These functionally differentiated subsystems are diverging but interdependent spheres of meaning with their own unique codes and with what Luhmann refers to as the symbolically generalized media of communication. [...] Once functional differentiation is entrenched, society can only be conceived of as a 'world society', for the symbolically generalized media of communication do not confine themselves to Western Europe and North America but instead spread all over the world. ${ }^{56}$

O único obstáculo para a assimilação de tal ideal passa a ser a questão de encarar o tempo como linearidade, e assim considerar que o oriente não tem maturidade suficiente para assim encará-lo, até porque ele cita ser

\footnotetext{
55 VERSCHRAEGEN (2002. p. 262)

56 VERSCHRAEGEN (2002, pp. 261-262) Tradução livre: Na verdade, a teoria dos sistemas distingue diferentes tipos de sociedade sob a égide da forma dominante (não única e exclusiva) de diferenciação social interna, ou da forma pela qual são construídos os subsistemas dentro do descompassado sistema social denominado sociedade. Esses subsistemas funcionalmente diferenciados são divergentes, mas esferas interdependentes de significado com seus próprios códigos e com a que Luhmann se refere como mídia simbolicamente generalizada de comunicação. [...] Uma vez que a diferenciação funcional é depreendida, a sociedade somente pode ser concebida como uma 'sociedade mundial', já que as mídias simbolicamente generalizadas de comunicação não se autoconfinam na Europa Ocidental e na América do Norte, mas ao contrário, se propagam por todo o mundo.
} 
imprescindível o contexto de sociedade moderna no primeiro excerto.

O que se propõe é que os direitos humanos atuem como autolimitação na seara das liberdades fundamentais. Partimos do pressuposto de que Luhmann admite regressões e desdiferenciações nos sistemas traçados.

Em escala macro, tais perturbações tendem a ocorrer no sistema político, em virtude de tomada drástica de decisões, que podem afetar toda a ordem. O impacto dessas decisões é ainda maior quando ocorrem no sistema político, uma vez que a tendência desse é subsumir os demais, em alguns casos, inclusive, sob o argumento da legitimidade democrática. Nesse contexto, a frenagem seria concedida pelo argumento dos direitos humanos.

Dessa forma, sob a perspectiva Luhmanniana, a DUDH parece estar resguardada de sua utilização como meio de imposição. Nesse sentido, cabe a reflexão de POMIAN, que faz um jogo de palavras com a questão da dominação, para sugerir que a única forma de dominação legítima seria paradoxalmente a de um povo universal e assim mesmo, somente sob o ponto de vista histórico.

Um povo é, pois, universal histórico quando exprime o Espírito do Mundo, quando, conservando em tudo a sua particularidade, revela ser portador do universal, encarnação de um princípio cuja realização é necessária ao avanço do espírito, do seu autoconhecimento e da sua liberdade, isto é, ao progresso do gênero humano visto como se construísse uma unidade. Neste sentido, é um povo dominante, e por este motivo a sua entrada em cena na história faz época. ${ }^{57}$

\subsection{A linguagem dos Direitos Humanos e os Direitos Humanos como linguagem}

Sobre a disparidade entre as instituições de direitos humanos e sua aplicação, muito da literatura mundial se posiciona no sentido da "human-rightstalk"58. É o caso de VILLEY:

Não é obrigatório que à palavra "direito" corresponda, ao longo dos séculos, uma mesma realidade. Talvez sejamos livres para construir uma sucessão infinita de definições "nominais" do direito, concedidas às nossas sucessivas ideologias políticas. Só que essa prática conduz a linguagem à incoerência e à confusão, como acabamos de constatar. $^{59}$

\footnotetext{
${ }^{57}$ POMIAN (1993, p. 189)

58 Human-rights-talk: termo designado pela escola inglesa analítica da linguagem, a qual sugeria que a o conceito de direitos humanos fosse desprovido de significado em razão de sua difícil implementação. Qual a referência para tal conceituação de human rights talk?

${ }^{59}$ VILLEY (2007, p. 23)
} 
Autores da mesma linha restritiva, cuja opinião possui maior peso nos estudos acadêmicos concluem que o problema de toda essa abstração seria o da consequência da dificuldade de implementação dos direitos humanos nesses moldes.

\begin{abstract}
Earthy or transcendent, their [philosophers, anthropologists and social theoreticians] reflections have been intellectually enticing but of little use or relevancy for the victims caught in the clutches of the modern state and intolerant cultures. [...] They are still learned individuals in different cultures who think that the "failure" of the United Nations to define clearly what the expression "human rights" mean has created practical problems for the enforcement of human rights around the world. $^{60}$
\end{abstract}

Sobre o assunto, os próprios membros da corrente abrangente defendem que a utilização de determinados termos ocorre em função do caráter dogmático dos direitos humanos, sem, no entanto, esvaziá-los de valor.

Despite all the historical evidence of the capacity of visions of human rights to transform attitudes, to create inspiration, and to provoke resistance, it is interesting that not all observers understand or appreciate this power. Instead, they dismiss these visions as "just dreams", "only words", "merely statements", or "impractical speculations" unlike to create anything than a ripple on the course of human events. ${ }^{61}$

\title{
No mesmo sentido sustenta SUPIOT. A dogmática tratada em seu excerto não é aquela da visão do primeiro grupo de conceituação dos direitos humanos e sim a do ponto ótimo em relação a sua aplicação.
}

Com efeito, é no terreno das crenças que se coloca a questão dos direitos humanos. Toda reflexão sobre o assunto deve começar por levar em consideração sua natureza dogmática e reconhecer que eles são os artigos de um credo oriundo dos valores da cristandade ocidental. Mas essa natureza dogmática não deve levar a desqualificá-los. Um dogma é também um recurso, talvez o mais indispensável à vida humana, já que a peculiaridade dessa vida é que os homens devem atribuir-lhe um sentido, mesmo quando ela não tem sentido nenhum demonstrável. ${ }^{62}$

E ainda se pode acrescentar:

\footnotetext{
60 AFSHARI (2007, p. 09) Tradução livre: Mundano ou transcendente, [filósofos, antropólogos e teóricos sociais] as suas reflexões foram intelectualmente sedutoras, mas de pouca utilidade ou relevância para as vítimas apanhadas nas garras do Estado moderno e culturas intolerantes. [...]. Eles ainda são os indivíduos aprenderam em diferentes culturas que pensam que o "fracasso" das Nações Unidas para definir claramente o que a expressão "direitos humanos" significa criou problemas práticos para a aplicação dos direitos humanos em todo o mundo.

61 LAUREN (1998, p. 284) Tradução livre: Apesar das evidências históricas da capacidade das visões de direitos humanos transformar atitudes, criar inspiração, e provocar resistência, é interessante que nem todos observadores entendem ou apreciam tal poder. Ao invés disso, eles repudiam tais visões como "apenas sonhos", "somente palavras", "meramente afirmações", ou "especulações impraticáveis" improváveis de criar algo mais do que uma ondulação sobre o curso dos eventos humanos.

62 SUPIOT (2007, p. 232)
} 
Mas para que os direitos humanos continuem a cumprir essa função dogmática, cumpre que a interpretação deles evolua na proporção do desenvolvimento histórico e da extensão geográfica das ciências e das técnicas. Isso supõe que os não-ocidentais os adotem e, assim, enriqueçam-Ihes o sentido e o alcance. Somente então os direitos humanos deixariam de ser um credo imposto à humanidade para se tornar um recurso dogmático comum aberto à interpretação de todos. $^{63}$

Numa posterior reflexão, LAUREN desafia os que se opõem a essa lógica a manterem sua opinião sobre o advento da DUDH.

Upon the adoption of the Universal Declaration of Human Rights, for example, any number of commentators tended to belittle the achievement. [...] In the light of the subsequent impact of the Universal Declaration of Human Rights, it is unlikely that they would hold these same opinion. ${ }^{64}$

Embora no caso de AFSHARI essa reflexão tenha sido recente e, portanto, posterior à DUDH, ele parece concordar com LAUREN quanto à essência da afirmação, uma vez que considera a DUDH uma ruptura epistemológica com o passado.

Soma-se o fato de que, a despeito do que se imaginava, pela experiência histórica percebemos que nem sempre a fluidez de conceituação representa entrave ao pleito desses direitos.

O fato é que os direitos humanos possuem uma dinâmica toda complexa em função do enaltecimento de sua carga semântica. Quando diante de violações, as reações são quase que instintivas.

Na parte final da obra do polêmico VILLEY, encontra-se uma carta escrita por um amigo que fez um primeiro comentário ao manuscrito. Nessa carta, há uma forte crítica ao posicionamento de VILLEY, inclusive com críticas à narrativa histórica enviesada utilizada na obra.

$\mathrm{Na}$ tentativa de explicar que os direitos humanos talvez sejam uma reação natural dos seres humanos ao verem praticada alguma injustiça, ele cria um personagem fictício para denotar que o fato é tão notório que até pesquisas científicas não denotariam outro resultado.

\footnotetext{
63 SUPIOT (2007. p; 233)

64 LAUREN (1998, p. 284) Tradução livre: Acerca da adoção da Declaração Universal dos Direitos Humanos, por exemplo, certo número de comentaristas tenderam a menosprezar a realização. [...] Sobre a luz do impacto subseqüente da Declaração Universal dos Direitos Humanos, é improvável que manteriam a opinião hoje em dia.
} 
E, sinto muito por você, mas essa linguagem é necessária. O público já não vai informar-se na Suma teológica nem na Ética a Nicômaco; ele lê a Imprensa e assiste à Televisão, está a par das realidades! Você ignora no que a Imprensa e a Televisão abeberam? Mas no Gulag, nas torturas de El Salvador; no enforcamentos de Komeini, em crianças esqueléticas, em meninas de doze anos vendidas na Tailândia a donos de bordéis! Você responderá que esses horrores nada têm de novo e que a história viu outros assim. Mas preste atenção que o homem de hoje foi criado para as idéias de Progresso, de Felicidade, e da Técnica das Previdências, ao passo que, antigamente, as crenças no Diabo, no Pecado, na Penitência e na "Cruz" etc. faziam aceitar a pílula. O choque é muito mais perturbador! No espectador instalado em sua poltrona em frente da televisão, meu amigo, o dr. Cheistowicz, com sua equipe notaram perturbações psicológicas, síndromes de culpa e pulsões incômodas, uma necessidade surda de reagir que desestrutura o subconsciente. Como nem todos saberiam reagir à maneira de Madre Teresa ou dos Médicos Sem Fronteira, a utilização dos direitos humanos, cuja oportunidade você parece desconhecer, é de rendimento infalível. ${ }^{65}$

\section{A despeito da brincadeira depreendida considerando a pesquisa do}

\section{fictício Dr. Cheistowicz e da reação quando da observação de telenotícias que veiculassem transgressões aos direitos humanos, reais estudos científicos apontam} para conclusões no mesmo sentido.

The answers were coded into 30 dummy variables corresponding to the 30 articles of the UDHR. ${ }^{66}$

Summing up the results, we were able to distinguish between three dimensions of attitudes toward human rights and found these dimensions consistently interrelated. Human rights endorsement, rejection of human rights restrictions, and negative attitudes toward military enforcement of human rights tended to do together. This cluster of attitudes, as well as human rights knowledge, was positively associated with human rights behavior, suggesting that it is possible to predict who, at least on the level of self-reports, gets engaged in behavior targeted at the promotion of human rights. ${ }^{67}$

We are able to predict self-reported human rights behavior by attitudes and knowledge, which in turn were predicted by general individual differences variables. It should be kept in mind, however, that we measured self-reported rather than real behavior. ${ }^{68}$

65 VILLEY (2007, p. 166)

${ }^{66}$ COHRS, MAES, MOSCHNER et KIELMANN (2007, p. 453) Tradução livre : As respostas foram codificadas em 30 variáveis postiças correspondentes aos 30 artigos da DUDH.

COHRS, MAES, MOSCHNER et KIELMANN (2007, p. 459) Tradução livre : Resumindo os resultados, fomos capazes de distinguir entre três dimensões de atitudes em relação aos direitos humanos e encontrarmos estas dimensões consistentemente inter-relacionadas. Endosso dos direitos humanos, a rejeição de restrições de direitos humanos, e as atitudes negativas em relação à aplicação militar dos direitos humanos tendem a caminhar juntas. Este conjunto de atitudes, bem como o conhecimento dos direitos humanos, foi positivamente associado com o comportamento de direitos humanos, sugerindo que é possível prever quem, pelo menos no nível de auto-relatos, fica comprometido com o comportamento orientado para a promoção dos direitos humanos.

68 COHRS, MAES, MOSCHNER et KIELMANN (2007, p. 462) Tradução livre : Somos capazes de prever o comportamento auto-relatado de direitos humanos por atitudes e conhecimentos, que por sua vez foram previstos por variáveis de diferenças individuais gerais . Deve ser mantido foco, no entanto, que medimos a auto-relatos, em vez de comportamento real. 
A proteção dos direitos humanos torna-se ainda mais essencial nos dias de hoje, pois os direitos humanos que antes emergiram para proteger 0 indivíduo de possíveis abusos por parte dos estados, na sociedade contemporânea, em virtude da globalização e demais fenômenos de intercâmbio e correspondência de bens, serviços e ideologias, passam a desempenhar também o papel de proteção do indivíduo em relação a outros entes, os quais, por vezes, possuem maior poder político do que alguns estados por si sós.

Sobretudo com o advento da globalização, no qual o intercâmbio não se restringe a mercadorias e atividades econômicas, resta imprescindível a defesa e a exigência de implementação dos direitos humanos por todos os países do globo.

Não só pelo fato de que o enorme fluxo de pessoas requer posicionamento ultra-fronteiriço das nações que pretendem proteger seus cidadãos que porventura se encontrem fora do território nacional, caso sejam vítimas de violações de direitos humanos, mas, sobretudo, por se tratar de direitos inatos e irrenunciáveis, inerentes à condição humana. LUÑES aduz: "En un mundo interdependiente; en el seno de sociedades interconectadas, la garantía de unos derechos universales se ha hecho más perentoria que nunca." ${ }^{69}$

69 LUÑES (2002, p. 27) Tradução livre: Em um mundo interdepente; no seio de sociedades interconectadas, a garantia de direitos universais se fez mais peremptória que nunca. 


\section{Conclusão}

O mundo atual globalizado, por meio do difundido acesso à informação e intercâmbios de outras naturezas, foi capaz de alterar a dinâmica das relações entre os mais diversos entes da comunidade internacional.

A esse respeito, não cabe referência única ao papel desempenhado pelos indivíduos, mas também pelos Estados, pelos organismos internacionais, pelas organizações não-governamentais, pelas grandes corporações, pela mídia internacional, pelas pequenas células de sociedade civil, entre outros.

Nesse ponto, é interessante notar que a perspectiva contemporânea não foi somente responsável por aproximar aqueles entre os quais a relação já era estabelecida, como inaugurou novas interações e permitiu o surgimento de novos atores. Os institutos não tendem a se relacionar somente com os de mesma categoria, sobretudo porque a interface acaba por ser condição de existência e manutenção no cenário internacional.

Os direitos humanos têm papel de destaque nesse aparato e emergem em toda discussão de relevância para a comunidade internacional. Isso porque eles têm a função de resguardar a célula mínima de toda a engrenagem de apreciação do direito internacional, que é o indivíduo.

Parece tratar-se de um raciocínio rudimentar para nós inserido no momento presente; Contudo, ele só adquiriu essa conformação no século XIX, onde se estabeleceu a primazia dos direitos humanos sob 0 ponto de vista da transcendência de sua repercussão aos limites do Estado.

Ao contrário, para que se chegasse à conformação atual de direitos humanos, um longo caminho foi percorrido. É essa análise que fazem os historiadores dos direitos humanos.

Percebemos que a historiografia dos direitos humanos é um tema de notória relevância, uma vez que o estudo da história é uma ferramenta de entendimento do presente e de prospecção do futuro e que, hodiernamente, a noção de direitos humanos é, ou ao menos deveria ser, onipresente nos estratos da sociedade. 
Dessa forma, podemos concluir que não só o passado factual, mas a forma como os fatos são narrados impactam no presente. Se assim o é, o método empregado nessa jornada tem consequências sobre as conclusões extraídas.

A literatura contribui com a separação das visões de direitos humanos em duas vertentes principais, quais sejam: uma restritiva e uma abrangente. A opção por uma em detrimento da outra reflete justamente o que o argumento acima pretende explicitar, pois, afinal, ambas possuem leituras completamente distintas do conceito de direitos humanos desde a sua evolução até sua implementação.

Sendo a questão da implementação dos direitos humanos um dos temas de maior relevância da atualidade, o questionamento que emerge é o das possíveis razões de sua ineficácia. Dentre essas possíveis razões se destaca a questão da diferença geográfica entre diversas populações e o acesso que essas possuem não só ao conceito, em termos de absorção do significado, como também à questão da implementação, quando os direitos, apesar de conhecidos, têm seu exercício dificultado.

Apesar de considerar esse abismo entre alguns destinatários da norma em relação a sua aplicação, os direitos humanos têm de ser encarados também como linguagem, pois é justamente essa perspectiva que concede ao conceito uma possibilidade de auto-validação. A semântica dos direitos humanos é o que permite que apesar de conhecidas violações ainda se adote o instituto de maneira dogmática e o eleja, talvez, como a opção mais viável a conter essas violações. 


\section{REFERÊNCIAS BIBLIOGRÁFICAS}

. DECLARAÇÃo UNIVERSAL DOS DIREITOS hUMANOS. Resolução 217 A (III) Organização das Nações Unidas. New York. USA. 1948. Disponível em: http://portal.mj.gov.br/sedh/ct/legis intern/ddh bib inter universal.htm .Acesso em13 ago 2011.

ACCIOLY, H. Manual de direito internacional público, $15^{\mathrm{a}}$ ed. Saraiva, 2002. São Paulo, SP. 566p.

AFSHARI, R. On Historiography of Human Rights Reflections on Paul Gordon Lauren's The Evolution of International Human Rights: Visions Seen. Human Rights Quaterly, v. 29, n. 1, p. 01-67, Feb. 2007.

AGAMBEN, G. Homo sacer: o poder soberano e a vida nua I. $2^{\underline{a}}$ ed. Tradução: Burigo, H. UFMG, 2010. Belo Horizonte, MG. 197p.

BAETS, A. The impact of the Universal Declaration of Human Rights on the study of History. History and Theory, v. 48, n. 1, p. 20-43, Feb. 2009.

CHAKRABARTY, D. Provincializing Europe: postcolonial thought and historical difference. Princeton, USA. Princeton University Press, 2000. 300p.

COHRS, C. ; MAES, J.; MOSCHNER, B. et KIELMANN. Determinants of Human Rights Attitudes and Behavior: A Comparison and Integration of Psychological Perspectives. Political Psychology, v. 28, n. 4, p. 441-69, Aug. 2007.

DAVIS, K. Periodization and sovereignty: how ideas of feudalism and secularization govern politics of time. Philadelphia. University of Pennsylvania Press, 2008. 20p.

DEVINE, C.; HANSEN, C. R. \& WILD, R. Direitos Humanos: Referências Essenciais. Tradução: Fábio Larsson. São Paulo. EdUSP, 2008. 484p

FLORES, M. Confrontare le atrocità: II ruolo dello storico. Storia, verità, giustizia: I crimini del XX secolo. Bruno Mondadori. Milano, 2001. p. 379-392

HUNT, L. A Invenção dos direitos humanos: uma história. Tradução: Rosaura Eichenberg. São Paulo: Companhia das Letras, 2009. 285p.

INGRAM, D. Between Political Liberalism and Postnational Cosmopolitanism: Toward an Alternative Theory of Human Rights. Political Theory, v. 31, n. 3, p. 35991, Jun. 2003. 
ISHAY, M. The Human Rights Reader: Major Political Essays, Speeches and Documents from Ancient Times to the Present. 2a Ed., Routledge, UK, 1993. $518 p$.

LASKI, H. Towards a Universal Declaration of Human Rights. A Collective Approach to the problems of Human Rights. Paris, France: UNESCO, 1948. p. 82-96.

LAUREN, P. G. The Evolution of International Human Rights: Visions Seen. Philadelphia. University of Pennsylvania Press, 1998. 385p.

LEGENDRE, P. L'amour du censeur: essai sur l'ordre dogmatique. Paris, France. Editions du Soleil, 1974. 269p.

LESAFFER, R. The end of the Cold War: an epochal event in the history of international law? Disponível em: http://www.esilen.law.cam.ac.uk/Media/Draft Papers/. Acesso em 23 nov 2011.

LUÑO, A-E. La universalidad de los derechos humanos y el Estado constitucional. Serie de teoría jurídica y filosofia del derecho. $n$ 23, p. 11-60 Universidad Externado de Colombia. 2002. Bogotá, Colombia.

MOYN, S. The Last Utopia: human rights in history. The Belknap Press of Harvard University Press. Cambridge, Massachusetts and London, England, 2010.337p

NEUMAYER, E. Do treaties improve respect for Human Rights?. The Journal of Conflict Resolution, v. 49, n. 6, p. 925-53, Dec. 2005.

POMIAN, K. L’ordre du temps. Éditions Gallimard. Paris, France, 1984. 365p.

. Periodização In: Enciclopédia Einaudi, v 29 - Tempo/temporalidade. Lisboa, Portugal. Imprensa Nacional, Casa da Moeda, 1993. p. 164-213.

RAJAGOPAL, B. International law and social movements: Challenges of theorizing resistance. Columbia Journal of Transnational Law, v. 41, n. 2, p. 397-433, Feb. 2003.

SUPIOT, A.. Homo Juridicus. Ensaio sobre a função antropológica do Direito. Tradução: Maria Ermantina Prado Galvão. São Paulo. WMF Martins Fontes, 2007. $283 p$. 
VERSCHRAGEN, G. Human Rights and Modern Society: A Sociological Analysis from the Perspective of Systems Theory. Journal of Law and Society, v. 29, n. 2. Feb. 2002.

VILLEY, M. O direito e os direitos humanos. Tradução: Maria Ermantina de Almeida Prado Galvão. São Paulo. WMF Martins Fontes, 2007.181p 